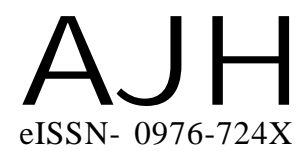

Article history :

Received : 17.10.2015

Revised : 07.11.2015

Accepted : 20.11.2015
Members of the Research Forum

Associated Authors:

${ }^{1}$ Regional Agricultural Research

Station (K.A.U.), Kumarakom, KOTTAYAM (KERALA) INDIA

Email : jayalekshmi.g@kau.in;

thusharareji@gmail.com

${ }^{2}$ Krishi Vigyan Kendra (K.A.U.), Kumarakom, KOTTAYAM (KERALA) INDIA

Email : elizebeth.rbn@gmail.com

Author for correspondence : ANU G. KRISHNAN

Regional Agricultural Research Station (K.A.U.), Kumarakom, KOTTAYAM (KERALA) INDIA Email : dranugk@gmail.com
THEASIAN JOURNALOF HORTICULTURE

Volume 10 | Issue 2 | December, 2015 | 262-266

Visit us -www.researchjournal.co.in

\title{
Assessment of physico-chemical properties of jackfruit collections from Kuttanad region of Kerala
}

\section{ANU G. KRISHNAN, G. JAYALEKSHMI ${ }^{1}$, ELIZEBETH JOSEPH² AND THUSHARA SUSAN SABU ${ }^{1}$}

ABSTRACT : Artocarpus heterophyllus Lam (Jackfruit) which belongs to the family Moraceae, is believed to be indigenous to the south western rain forest of India. It is an important component of homestead gardens in Kerala. A lot of variability exists among jack trees as most of them are raised from seedlings. Hence, a study was conducted at Regional Agricultural Research Station, Kumarakom during 2011-14 to assess the variation in fruit quality and bearing habit of jack trees grown under the agro climatic conditions of Kuttanad and to recommend the promising types of jack types suitable to this region. To identify the superior indigenous jackfruit types a survey work has been carried out in Kuttanad region and identified 21 firm fleshed jack types. Organoleptic test was conducted for these genotypes and selected 10 promising types with good sensory quality. Physico-chemical properties of these genotypes were evaluated. A significant variation in physico-chemical characters of jackfruit were observed among these jack selections. The physical characters of fruit such as individual fruit weight ranged from 1.69 to $17.50 \mathrm{~kg}$, bulb mass $0.80-10.25 \mathrm{~kg}$, flake mass $0.64-6.62 \mathrm{~kg}$, single bulb weight $13.20-48.36$ $\mathrm{g}$ and flake thickness $0.31-0.63 \mathrm{~cm}$. Similarly, the chemical parameters also varied significantly among these selections. The TSS varied from 12.60 - $31.80{ }^{\circ}$ Brix, ascorbic acid 1.50 - $10.55 \mathrm{mg} /$ $100 \mathrm{~g}$, acidity 0.20 - 1.02 per cent, total sugar $20.84-61.88$ per cent and reducing sugar $3.18-9.39$ per cent. The selected superior jack types met the standard parameters for high quality fruits, and can be recommended for their performance and sustainable yield in such type of environment. These promising selections were propagated through patch budding and are maintained in our station as part of our germplasm conservation. The result of this study is a useful information for further crop improvement programmes in jack.

KEY WORDS : Artocarpus heterophyllus Lam., Jack fruit, Physico chemical properties

HOW TO CITE THIS ARTICLE : Krishnan, Anu G., Jayalekshmi, G., Joseph, Elizebeth and Sabu, Thushara Susan (2015). Assessment of physico-chemical properties of jackfruit collections from Kuttanad region of Kerala. Asian J. Hort., 10(2) : 262-266. 